\title{
Shashi Deshpande's That Long Silence A Paradigm Of Communication Breakdown
}

\author{
Dr. Jabeen R. Siddiqui
}

\begin{abstract}
Shashi Deshpande is an award winning novelist and a short story writer. Her novels replicate their high significant minds of women's identity seem to disclose the vital and classic theme of feminist literature. Her novels are deeply rooted in India and she describes the Indian society. The women writers of Indian English literature have prominently contributed to improve modern Indian English fiction. The boredom and total dullness of life of a woman with substance comfort is brilliantly represented. She makes an attempt to explore the inner psyche of the modern women who are at the cross lines between tradition and modernity. This paper describes the lack of communication in the novel that long silence between the protagonist Jaya and her husband Mohan orally and emotionally. There is scarcely any communication amid Jaya and Mohan, neither vocal nor poignant. The symbol of silence for her is a withdraw, a protective method which helps her to articulate herself more meticulously and pleasingly. Her warm longing of adolescence are distorted into rigid rules and rituals by tradition. Her husband Mohan was not an empathetic listener which caused Jaya to feel alone and forlorn. It is proved that emotional suppression is more destructive for marital satisfaction as Jaya is disturbed, covert and subjugated in the novel and she marches ahead for her betterment. It also suggests honesty, clearness and listening factors between spouses for a healthy marriage.
\end{abstract}

Keywords: Identity, communication, emotionally, suppression, disturbed, subjugated.

\section{INTRODUCTION}

Shashi Deshpande is an award winning novelist and short story writer. She is a master writer in the way she articulates human emotions and relationships, the fears and feelings experienced by humans by women. Shashi Deshpande novels replicate their high significant minds of women's identity seem to disclose the vital and classic theme of feminist literature. Her novels are deeply rooted in India and she describes the Indian society. She is a Sahitya academy award winner for this novel That long silence. Women writers of Indian English literature have prominently contributed to improve modern Indian English fiction. Distinguished feminist critics and writers like Kate Miller, Simon De Beauvoir, Anita Desai, Virginia Woolf and Shashi Deshpande have made a notable contribution to the literature of feminism. The women novelists look at the psychic and ethical dilemmas and effects of the condition in their women characters trying to attain a new accord of relationships with themselves and their ambience. In this novel the author had exposed the captivating image of an educated middle class woman. She has explained the dilemma of learned women after conjugal life. She makes an attempt to explore the inner psyche of the modern women who are at the cross lines between tradition and modernity. She focuses on women in her writings, tries to value them, their past, their roles and their place in the world, and above all their associations with others. In That Long Silence Shashi Deshpande describes the subtle undulation of mood, the see- saw moments of delight and desolation, the flotsam and jetsam of feelings professed and suppressed the life of senses as well as the heart wringing agony of the storyteller. Shashi Deshpande's Fiction includes If I Die (1982), Roots And Shadows(1983), Come Up And Be Read(1985)The Dark Holds No Terrors(1980),That Long Silence(1988),The Binding Vine(1993,A Matter Of Time (1996) and Small Remedies(2000).

Each event a small story, a short story in itself, imparts an unfamiliar dream to the narrative. Contemporary Indian writers like Deshpande tend to represent the subjugation of women with better self awareness a deeper astuteness of participation and often with a sense of anger. She refuses to exoticize India in her creative writing. The boredom and total dullness of life of a woman with substance comfort is brilliantly exposed. The novel contains zero outside the narrator's tapered life range. This paper describes the lack of communication between Jaya the protagonist and her husband Mohan orally and emotionally.

\section{DISCUSSION:}

Shashi Deshpande's admirably sensible portrayal of the modern Indian women's condition and the sensible elucidation she puts forward harmony in her novels, an everlasting significance for their positive persuasive marriage for women and the whole civilization as well. Women's writers of Indian English fiction have considerably contributed to the strength, diversity, human race and creative truthfulness. In That Long Silence, Deshpande raise the strong voice of disapproval in opposition to the male conquered Indian society and against 
man made regulations and conventions. Deshpande is also a good craftsperson. She knows that act lies in saying a thing but rather in showing a thing. Hence, she is very careful in budding a plot and character and their proper dealings, emotional study of the characters, imagery and descriptions, language and rhythm, and the weaving of all of them into a living whole. She tries to institute that it is not only the patriarchal set up which is accountable for the women's situation in the Indian society. The accountability also slander inside the sufferer to reject, to elevate a voice and to accomplish the target. The novel also traces the development of the protagonist from a condition of weakness, feeling of breakdown to that of relaxation. The whole feel of the fiction has been engraved out just about the innermost character Jaya who fights for the self. She finds herself a perplexed brained woman oscillating between vision and repulsion to fit well in the channel of conservative wife and mother.

One knows that communication is the course of transferring information from one person to another; it is the act of involvement or exchanging information, facts or judgments. Spouses who do not converse well with their other half do not always have a strong relationship. The communication does not require to be by means of words alone, undemanding acts of patting, caressing, or holding hands are a great form of communication. They soften resentments over supposed or actual slights, link distances, and create constructive power.

The Protagonist Jaya is a contemporary mess and the torrent of awareness that ensues out of it . At The outset Jaya is apparently a satisfied house wife married to a conscientious man of social status. Her husband Mohan was a conformist and he gave her not much freedom. He had very clear ideas about himself. He was a dutiful son, a dutiful father, husband and brother. He possess a passion for cleanliness and neatness and was a fastidious man. Between two of them the relationship was a noiseless flow of judgment, lack of communication and opinions. Mohan was having the prime position and Jaya the inferior one. He had a clear idea of what he wanted to lead, the kind of home he would live in and she went along with him. They shared very delicate and balanced relationship. With confusion Jaya spokes:

"A pair of bullocks yoked together.....that was how $i$ saw the two of us the day we came here. It was an eerie sensation I had while climbing the stairs with him, as if there was for that one infinitesimal moment a pause in my being, and $i$, detached from myself, saw this... a pair of bullocks yoked together. Then the focus shifted and there were instead a man and a woman climbing the dingy stairs of a drab building in stairs of a drab building in the heart of Bombay".(That Long Silence,7).

Despite her marriage she suffered from remoteness and subsequently became a mother of two children Rahul and Rati. Jaya succumbs and surrenders to Mohan without revolting. She is frayed between love and hate, fondness and disliking for her own husband and life situations. A dominating husband and an afflicted wife that is her tie with Mohan. Jaya lies lonely in her room, her mind shuttles amid the past and the present and thus covers the whole duration of her life. There is scarcely any communication amid Jaya and Mohan, neither vocal nor poignant. The symbol of silence for her is a withdraw, a protective method which helps her to articulate herself more meticulously and pleasingly. Occasionally Mohan also hugged, touched and caressed her but it was never a cheerful thing for both of them. He was thoughtless, extravagant, reckless and susceptible and she was alert, self centred, mature prudent, obedient and perceptive. Deshpande had thus painted the Jaya's substandard position and the ensuing degradation in a male dominated society which is a private life .

"In many respects women's lives, experiences and values have been treated as marginal and men's experiences have been assumed to be normative. In addition, there has been a general tendency to assume that important activities are those, which occur in the public, sphere, while private life and feelings are less important, of concern only to the individuals involved. This assumption can easily lead to the result that literature by and about women is undervalued or dismissed."(Sherry R:Studying Women's Writing,6.)

In Mohan's observation a victorious life can be calculated only in conditions of wages, wearing high-priced clothes and chatting good English and sending children to excellent school. As stated by the author Indian husbands take in for settled their wives emotions, likes and dislikes to be same like them and here author reciprocates the emotions in dramatic detail. The husband never realizes where he lacks and the anguish behind his wife's certain roles. He didn't listen to his wife's own story. Living despondently Jaya followed Vanitamami's suggestion that a husband is like a sheltering tree which must be kept alive at any cost, for without it the family becomes desolate and susceptible. She does so and finds herself and the children more lonely and apprehensive. She accepted and tolerated spouse's negative and destructive pattern of relating, it means working towards change. As Dwight Small says:

"The heart of marriage is its communication system......but no couple begins marriage with highly developed communication. It is not something they bring into marriage ready, but something to be continually cultivated through all the experiences of their shared life."( Communication: Key To Your Marriage: The Secret To True Happiness, 6).

Silence manifests in Jaya's restlessness which is more private and intensely sexual. Her loving longings of youth are distorted into stiff regulations by tradition. Jaya's inner chaos is so stressed and sensitive that words fall short for her yearning for communication. She is powerless to tell her problem out for she is a woman who faces the agony of her life and the antagonism of the environment in the proper spirit of perfect Hindu

DOI: 10.9790/0837-2203065962 www.iosrjournals.org $\quad 60 \mid$ Page


womanhood where respect and faithfulness has degenerated to the condition of determined subservience. Temperamental incompability between Jaya and Mohan accounts for their incommunication and quizzical silence. Enhanced education and employment opportunities have fashioned a new consciousness among Indian women. In the words of Veena Noble Das it is noted that :

"The Indian woman caught in the flux of tradition and modernity bearing the burden of the past and the aspirations of the future is the crux of feminism in India. A search for identity and a quest for the definition of the self have become prime features of women in literature under the sway of feminism.".

( Feminism And Literature,11).

Shashi Deshpande portrays that woman firstly had to give importance to their husband's home and family than career. There is only a waiting game in a woman's life. she has to wait to get married, wait for husband to come, wait for in-laws and wait for kids. Jaya is same as Anita Desai's Nanda Kaul in Fire On The Mountain who being heartlessly subjugated by her husband but perform her job loyally towards her folks. Jaya had done nothing but waited in her life for others, waited for a disaster and for a tragedy. She has not acknowledged herself. Deshpande presents here not a woman who has a wish to rebel but the one who finally reconciles to her unfortunate lot. As Jaya mentions:

"A Woman can never be angry she can only be neurotic, hysterical, frustrated. there's no room for anger in my life, no room for despair, either. There's only order and routine-today, I have to change the sheets; tomorrow, scrub the bathrooms; the day after, clean the fridge......."(That Long Silence 147-148).

Jaya's anguish and nervousness crippled her psychologically and expressively. Subsequently there cannot be a more contented and better conversation between Jaya and Mohan. It is a still a great catastrophe that the two sets of different minds are bound not only to live together but also to contribute bed and body. But in this novel the husband stands for dictatorial attitude and Jaya the wife symbolises desperate hope. The crooked practices of her husband in his office and his overgrowing resentment towards her creative profession form a wide gap between them, and they accept an indestructible yet uncomforting quietness towards each other. Due to irritation and loneliness she relates to Kamat her neighbour and makes sexual advances. After his passing away, she lives with emptiness with Mohan and all these failures reflects in her writings and loses her own visualization. She wrote about light, entertaining pieces about the travails of a middle-class housewife which was disliked by Mohan.

Jaya even could not enjoy the liberty of expression in writing. Mohan decides the content and context of Jaya's resourcefulness. He all the time deliberately or automatically maltreats the affectionate passion of Jaya. Silence manifests in Jaya's dissatisfaction which is more private and totally sexual. Her internal disagreement and chaos are so bitter that she is not capable to converse them out and remains quiet in order not to be bothered and disappointed after frustration of her action by the society. Her warm longing of adolescence are distorted into rigid rules and rituals by tradition. The couple hardly spoke to each other of love and sex. Lovemaking for them was a noiseless and tongue-tied affair. Mohan used to appreciate her and the hostility would follow into:

"God, how terrible it was to know a man so well. I could time it, almost to the second, the whole process of our lovemaking, from the first devious wooing to the moment he turned away from me, offering me his hunched back." (That Long Silence.85).

Jaya faces physical attacks at the hand of her husband and bears pain also because she does not conceive to be mother. It is pleasant to think that Jaya's sorrow and nervousness disabled her mentally and psychologically. She astoundingly feels that being collapse as a wife she faces unfriendliness character.

"Negation alone can never lead a woman towards selfhood. A wife's relation with her husband must take from within the totality of her life as a woman, only then it can lead to a harmonious experience."

( Rashmi Gaur, That Long Silence: Journey Towards self Actualisation in women in the Novels of Shashi Deshpande ed. By Suman Bala.).

That Long Silence is not an invasion into the world of silence but a silent close association with the exploited self straining for expression, for a tone to be heard. Through close-ups and flash back, Deshpande has exposed the consciousness of Jaya which is half-heartedly receptive and submissively secluded. Jaya astoundingly feels that being failure as a wife she traces self estrangement outlook. She became mad or weird because of the constant pressure of nerve caused by pain and suffocation. She finds nothing meaningful in this life if it rotates around the desire of her husband only. She seems to be a spilt personality because of the unvarying disagreement and immense pressure of self delusion and living reality. Isolation, anguish and disturbance in marriage for a while cause dissolution and make women disobedient. The Wright,N.H had well portrayed a couple missing emotional understanding:

"Some people are like medieval castles. Their high walls keep them safe from being hurt. They protect themselves emotionally by permitting no exchange of feelings with other. No one can enter.They are secure from attack. However, inspection of the occupant finds him or her lonely, rattling around his castle alone. The castle dweller is a self made prisoner. he or she needs to feel loved by someone, but the walls are so high that it is difficult to reach out or for anyone else to reach in ". ( Communication: Key To Your Marriage: The Secret To True Happiness, 14.) 
Jaya's feminine self is entrenched in her family which is overpowered. It is said that the family is a cage where the wild self inextricably is fascinated and extraordinarily reared. The women have been usually considered as preferably warm, kind and submissive, who are to be set aside in subordination to the male members of the family. Manu Proclaims:

"Day and night, women must be kept in subordination to the males of the family: in childhood to the father, in youth to her husband, in old age to her sons. Even though the husband be destitute of virtue and seeks pleasure elsewhere, he must be worshipped as God ." ( A Feminist Study,1.)

In spite of the same opportunities of education and money-making liberty, women remained a sufferer of domestic prejudice within the family, and other legal rights outside. The marriage had made her judicious, desperate and had to cross many bad situations in life. They have been deprived of the self-determination to express their judgments, feelings and distress. In Nayantara Sahgal's Storm in Chandigarh Saroj the protagonist is discontented not being able to hit upon a mutual emotional association with her husband Inder. In Shobhaa de's Second Thoughts Ranjan also didn't talk appropriately with Maya. His mocking tone and disrespect always hurts Maya and the bond never develops pleasingly. The great novelist Anita Desai also explores the distressed mind of the modern Indian woman who face lonesomeness and lack of proper communication. In her novel Cry, the peacock, the continuous widening fissure in communication between Gautama and Maya is explored all the way through the novel. There are different reasons of lack of communication in different novels endeavouring the human problems. The novelist Shashi Deshpande at earlier has given shock, anger and grief to the protagonist Jaya but ultimately she changes the situation and enables the protagonist to understand the situation and grabble the life problems and rebuild her relationships.

\section{CONCLUSION}

Shashi Deshpande a stupendous Indian English writer in her novels exposes togetherness and separation, presence and absence, reappearance and reunion; in detail everything that is associated to the psychodynamics of relationships. In the Novel the protagonist Jaya is aware of the great societal discrimination and unfairness towards her and resist against the repressive and uneven nature of the social norms and regulations that limit their potential and survival as wife. Silence in this novel introduces not only the lack of communication but the breakdown of indication to signify.

Jaya became detached from everything and became petrified about her career, about her writing. It is noted that Mohan could not understand her emotions as a result she was torn from within and also he was not an empathetic listener which caused Jaya to feel unaccompanied and desperate. There was no meaningful relationship between them because he always thought her inferior and there was no exchange of innermost thoughts and desires. Jaya, the protagonist, is so much puzzled about the total set up and the actions around her that she adopted the silence as a mode of her way of communication.

Deshpande through this novel uplifted the condition of women and raised her voice for treating women as a human being and this piece of literature suggest to consider women on emotional level rather escaping her from collapsing because hers is a great sacrifice. It is proved that emotional suppression is more destructive to women for marital satisfaction .In this novel it has lowered Jaya's relationship satisfaction as Jaya is alienated, undeveloped and subjugated in the novel and she marches ahead for her betterment. The paper recommends empathy, helpful listening, compassion, sharing good wishes, honesty, lucidity and simple spending moments with each other in a marriage .Consequently; the problem of lack of communication has been worked out imposingly by Shashi Deshpande.

\section{REFERENCES:}

[1] Deshpande, Shashi. That Long Silence. Haryana, Gurgaon: Penguin Books India Ltd, 1988, .7.

[2] Sherry, Ruth. Studying Women's Writing; In Introduction. London: Edward Arnold,1988,6.

[3] Wright, N .H. Communication: Key To Your Marriage: The Secret To True Happiness.2012, 6.

[4] Das, V.N. Feminism And Literature .New Delhi: Prestige Books, 1995, 11.

[5] Deshpande, Shashi. That Long Silence. Gurgaon, Haryana: Prestige Books, 1988, 147-148.

[6] Ibid; 85

[7] Gaur, R. That Long Silence: Journey Towards Self Actualisation In Women In The Novels Of Self Actualisation In Women In The Novels Of Shashi Deshpande Ed. By Suman Bala. Print.

[8] Wright, N .H. Communication: Key To Your Marriage: The Secret To True Happiness.2012, 14.

[9] Sharma Siddharth. Shashi Deshpande's Novels: A Feminist Study. New Delhi: Atlantic Publishers And Distributors, 2005,1 . 